\title{
Factors Related to the Risk of Occupational Stress among Nurses in the Emergency Room at Sosodoro Djatikoesoemo Bojonegoro Hospital
}

\author{
Faktor Terkait Risiko Stres Kerja pada Perawat Instalasi Gawat Darurat di Rumah \\ Sakit Sosodoro Djatikoesoemo Bojonegoro
}

\author{
Rizqi Supramulyana Putra, Tya Nisvi Rahmadhani, Sho`im Hidayat \\ Department of Occupational Safety and Health, Faculty of Public Health Universitas Airlangga \\ Campus C Mulyorejo, Surabaya, East Java 60115
}

\begin{abstract}
Introduction: Occupational stress is a body response that is present in the form of physiological, psychological, and behavioral responses to stressors in the work environment. If this condition is not handled properly, it will have a negative impact on workers, and it can reduce the level of health and cause several diseases. The purpose of this research was to determine the risk of occupational stress among nurses in the Emergency Room at Sosodoro Djatikoesoemodan Hospital and what factors were related to the risk of occupational stress. Methods: This research is a descriptive observational study with respondents consisting of 26 nurses in the Emergency Room at Sosodoro Djatikoesoemo Hospital. Data collection was done using questionnaires to measure the level of occupational stress risk of nurses, which included variables of individual worker's characteristics and job characteristics. The data analysis in this study used the Spearman correlation. Results: The results showed that $15.4 \%$ of nurses had a low level of occupational stress risk, $69.2 \%$ had a moderate level of occupational stress risk, and $15.4 \%$ had a high level of occupational stress risk. Moreover, there was a significant relationship between social support and workload factors on the risk of occupational stress. Conclusion: Most of the nurses experienced moderate occupational stress. Gender, personality type, workload and mental demands were factors that were related to the risk of occupational stress and could increase the risk of occupational stress. Meanwhile, interpersonal conflict and job control were elements that were not related to the risk of occupational stress.
\end{abstract}

Keywords: emergency room sododoro djatikoesomo hospital, nurses, risk of occupational stress

\section{ABSTRAK}

Pendahuluan: Stres kerja yakni sebuah tanggapan tubuh yang hadir berupa respon fisiologis, psikologis, dan perilaku terhadap stressor di lingkungan kerja. Kondisi ini jika tidak ditangani dengan baik akan membawa dampak buruk bagi pekerja yaitu dapat menurunkan tingkat kesehatan hingga terkenanya sebuah penyakit. Tujuan dari penelitian ini yakni untuk mengetahui risiko stres kerja pada perawat Instalasi Gawat Darurat Rumah Sakit Sosodoro Djatikoesoemodan beserta faktor apa saja yang berhubungan dengan risiko stres kerja tersebut. Metode: Penelitian ini merupakan penelitian deskriptif observasional dengan responden yang terdiri dari 26 perawat Instalasi Gawat Darurat Rumah Sakit Sosodoro Djatikoesoemo. Pengumpulan data menggunakan kuesioner untuk mengukur tingkat risiko stres kerja perawat yang meliputi variabel karakteristik individu pekerja dan karakteristik pekerjaan. Dalam penelitian ini analisis data yang digunakan yaitu korelasi Spearman. Hasil: Hasil penelitian menunjukkan bahwa 15,4\% perawat mengalami risiko stres kerja tingkat rendah, 69,2\% tingkat sedang, dan 15,4\% tingkat tinggi. Terdapat hubungan yang signifikan antara faktor dukungan sosial dan beban kerja terhadap risiko stres kerja. Simpulan: Sebagian besar perawat mengalami stres kerja sedang. Jenis kelamin, tipe kepribadian, beban kerja dan tuntutan mental merupakan faktor yang berhubungan dan dapat meningkatkan risiko stres kerja. Konflik interpersonal dan kontrol terhadap pekerjaan merupakan elemen yang tidak berhubungan dengan risiko stres kerja

Kata kunci: instalasi gawat darurat rumah sakit sosodoro djatikoesoemo, perawat, risiko stres kerja

Corresponding Author:

Rizqi Supramulyana Putra

Email:rizqi.supramulyana.putra2016@fkm.unair.ac.id

Telephone: +6281357952957

\section{INTRODUCTION}

Stress is a depressed feeling disorder experienced by humans. At work, all the effects of stress will lead to decreased performance, efficiency and work productivity (Tarwaka, 2014). Stress 
can consist of physical and emotional disorders caused by inappropriate workloads, poor social environment, conflicts that occur, as well as dangerous work environments (Satmayani, Syahrul and Saleh, 2018). This can affect the safety and health of workers and can lead to health problems such as coronary heart disease, hypertension, and various other diseases induced by occupational stress. Besides, occupational stress also causes work accidents, loss of motivation and high incidence of absenteeism (Karima, 2014).

Health service sectors are jobs that have a high risk of stress. Human responsibilities in the health sector make workers more vulnerable to stress. Nurse medical staff had the highest proportion of stress, reaching $49 \%$ with a total of 296,876 people (Kemenkes, 2017). According to Perwitasari et al. (2016), all professional staff at the hospital has a risk of stress, but nurses have a higher stress level. In other words, nurses easily have an occupational stress (Yanto and Rejeki, 2017).

The work unit at the hospital that needs special attention is the nurses at the Emergency Room (IGD) (Martyastuti, Isrofah and Janah, 2019). This is because the emergency department is an important unit in the operation of a hospital and the main gate for the entry of emergency patients operating 24 hours (Fajrillah, 2016). The workload given to nurses on duty in the Emergency Room is very volatile because of the number of patients who come, and the level of seriousness of medical care that must be performed cannot be predicted. The workload of a nurse will be heavier due to long shifts, lack of rest time, the expectation of hospital leaders to always provide the best service, family demands for patient safety, and so forth (Handini, 2013).

The individual characteristics of nurses include age, gender, years of service, level of education, social support, personality type and occupational factors including interpersonal conflict, physical workload, mental demands, and control of work (Zavanya, 2019). However, the work environment cannot be assessed because the nurses are in the same room so that the assessment is likely to be homogeneous. Therefore, it is necessary to conduct a careful assessment of the occupational stress experienced by nurses in the Emergency Room and what factors affect the occupational stress in order to be able to improve the performance of nurses and the quality of health services in hospitals.
Sosodoro Djatikoesomo Bojonegoro Hospital is designated as a type B hospital that has 12 accredited services including Emergency Room (IGD), Outpatient Installation, Inpatient Installation, Laboratory Services, Pharmacy Services, Central Surgical Installation, CSSD Services, Integrated Administrative Services, Blood Bank Services, Radiology Services, Nutrition Services, and Hemodialysis Services. Emergency Room (IGD) is a unit service in hospitals that provide services for people experiencing acute illnesses and those who have experienced trauma in accordance with the standard sets (Amri, Manjas and Hardisman, 2019). Emergency Room (IGD) is a unit that operates for 24 hours and plays an important role in hospital operations as the main gate for the entry of emergency patients (Sulistyawati, Purnawati and Muliarta, 2019). The number of nurses at the Sosodoro Djatikoesoemo Bojonegoro Hospital were 26 people who were divided into 3 work shifts (morning, evening, and night shift) with a total of 8 nurses working a day without rest. Work shifts are carried out to meet service needs (Nur aini, 2019). The average number of patients admitted every day is $>60$ patients. When comparing the number of nurses and patients in one day, one nurse can handle 3-4 patients.

This research aims to determine the occupational stress load and what factors affect nurses in the Emergency Room at Sosodoro Djatikoesoemo Bojonegoro Hospital, so that prevention, repair, and improvement of control can be carried out to maintain the quality of nursing performance in the Emergency Room at Sosodoro Hospital Djatikoesoemo Bojonegoro. Moreover, this study aims to see the prevalence risk of occupational stress on nurses at the Sosodoro Djatikoesomo Bojonegoro Hospital Emergency Room and what factors are related to occupational stress.

\section{METHODS}

This research is an observational research conducted by observing the object of research without treatment. This research has passed the ethical clearance with the ethical clearance cetificate number 447/HRECC.FODM/VII/2019.

This research was conducted at the Emergency Room of Dr. Hospital. R. Sosodoro Djatikoesoemo Bojonegoro. This research is a cross sectional study because the variable data were obtained at one time. The preparation of proposals and permits was carried 
out from September 2018 to July 2019. The analysis system used was included in analytical research, using the Spearman correlation test to find out the relationship between variables; category 0 means there was no correlation between two variables, $>0-0.025$ means the correlation was very weak,> 0.25-0.5 means the correlation was sufficient, $>0.5$ 0.75 means the correlation was strong, $>0.75-0.99$ means the correlation was very strong and 1 means the correlation was perfect.

The population in this study were all nurses at the Sosodoro Djatikoesoemo Bojonegoro Hospital Emergency Room, with a total of 26 nurses, and the sampling of this study used the total population.

The measuring instruments used in this research were questionnaires containing questions about job factors to assess the risk of occupational stress experienced by workers, namely HSE Indicator Tools and NIOSH Generic Job Stress. The independent variables in this research were individual characteristics (sex, age, education level and years of service), work characteristics (interpersonal conflict, workload, mental demands and job control). Meanwhile, the dependent variable in this study was occupational stress.

\section{RESULTS}

Regional General Hospital (RSUD) Dr. R. Sosodoro Djatikoesoemo Bojonegoro is a noneducational type B hospital. Data Characteristics of respondents consisted of age, gender, education level and years of service.

Table 1 shows that the gender characteristics were divided into two general categories, namely men and women with the majority of respondents being women $(57.70 \%)$. Moreover, the age groups of respondents were divided into 5 age groups namely $<25$ years old, 26-30 years old, 31-35 years old, 36-40 years old, and $>40$ years old. Specifically, the majority of respondents were aged 26-30 years $(53.80 \%)$, followed by those aged $<25$ years old $(11.50 \%), 31-35$ years old $(7.70 \%), 36-40$ years old $(7.70 \%)$ and $>40$ years old $(19.20 \%)$ respectively. Furthermore, the years of service of respondents were classified into 5 categories, namely $1-5$ years, 6-10 years, 11-15 years, 16-20 years and $>21$ years. The the majority of respondents had worked for 1- 5 years $(46.30 \%)$, followed by those having been working for6-10 years $(30.80 \%), 16-20$ years $(15.40 \%)$, and $>21$ years (7.70). Interestingly, no one had a service period of 11-15 years. Furthermore, regarding the educational characteristics of respondents, the majority of respondents' education was Diploma $(57.70 \%)$, followed byBachelor (34.60\%) and Profession (7.70\%).

Table 2 shows that the distribution of occupational characteristics was divided into four namely interpersonal conflict, workload, mental demands, job control. Each was divided into three general categories namely low, medium and high. In interpersonal conflict the majority of respondents experienced moderate interpersonal conflict $(53.80 \%)$, the rest were in the low category $(46.20 \%)$, and none were in the high category. Furthermore, the majority of workloads were low workloads $(57.70 \%)$, the rest were moderate workloads $(42.30 \%)$, and none were included as heavy workloads. Furthermore, the mental demands of the majority of respondents were severe mental demands $(57.70 \%)$, the rest were moderate $(42.30 \%)$, and none were included as low mental demands. In addition, job control of the majority of respondents were included in the less category $(61.50 \%)$, the rest were in the enough category $(38.50 \%)$, and none were included as good control of work.

Table 1. Distribution of Research Respondents' Characteristics namely Gender, Age, Education Level and Years of Service at Sosodoro Djatikoesoemo Bojonegoro Hospital in 2019

\begin{tabular}{lcc}
\hline $\begin{array}{l}\text { Characteristics of } \\
\text { Respondents }\end{array}$ & Frequency (n) & Percentage (\%) \\
\hline Gender & 11 & 42.30 \\
Male & 15 & 57.70 \\
Female & & \\
\hline Age (years old) & 3 & 11.50 \\
$<25$ & 14 & 53.80 \\
$26-30$ & 2 & 7.70 \\
$31-35$ & 2 & 7.70 \\
$36-40$ & 5 & 19.20 \\
$>40$ & & \\
\hline Education Level & 15 & 57.70 \\
D3 & 9 & 34.60 \\
S1 & 2 & 7.70 \\
Profession & & \\
\hline Years of service & 12 & 46.30 \\
$1-5$ & 8 & 30.80 \\
$6-10$ & 4 & $15: 40$ \\
$16-20$ & 2 & 7.70 \\
$>21$ & & \\
\hline & & \\
\hline & & \\
\hline & & \\
\hline
\end{tabular}


Table 2. Distribution of Characteristics of Occupational Factors, namely Interpersonal Conflict, Workload, Mental Demands, Job Control and Occupational Stress Risk at Sosodoro Djatikoesoemo Bojonegoro Hospital in 2019

\begin{tabular}{|c|c|c|}
\hline $\begin{array}{c}\text { Characteristics } \\
\text { of Occupational } \\
\text { Factor }\end{array}$ & Frequency (n) & Percentage $(\%)$ \\
\hline \multicolumn{3}{|l|}{$\begin{array}{l}\text { In t e r p e r s o n a l } \\
\text { Conflict }\end{array}$} \\
\hline Low & 12 & 46.20 \\
\hline Moderate & 14 & 53.80 \\
\hline Weight & 0 & 0.0 \\
\hline \multicolumn{3}{|l|}{ Workload } \\
\hline Low & 15 & 57.70 \\
\hline Moderate & 11 & 42.30 \\
\hline Weight & 0 & 0.0 \\
\hline \multicolumn{3}{|l|}{$\begin{array}{l}\text { Mental Demands of } \\
\text { Respondents }\end{array}$} \\
\hline Low & 0 & 0.0 \\
\hline Moderate & 11 & 42.30 \\
\hline Weight & 15 & 57.70 \\
\hline \multicolumn{3}{|l|}{ Job Control } \\
\hline Less & 16 & 61.50 \\
\hline Enough & 10 & 38.50 \\
\hline Good & 0 & 0.0 \\
\hline \multicolumn{3}{|l|}{$\begin{array}{l}\text { Occupational Stress } \\
\text { Risk }\end{array}$} \\
\hline Low & 4 & 15.40 \\
\hline Moderate & 18 & 68.20 \\
\hline High & 4 & 15.40 \\
\hline
\end{tabular}

Based on the categories of occupational stress on respondents, the categories were divided into 4, namely low, medium, high and very high risk level of stress. The majority of respondents experienced moderate stress levels $(68.20 \%)$, and there was a similar percentage in the low and high categories $(15.40 \%)$; none had a very high level of stress.

Based on the results in Table 3, out of a total of 26 respondents in this study the percentage of male respondents experiencing low risk of occupational stress was $27.3 \%$, moderate risk of occupational stress was $63.6 \%$, and high risk of occupational stress was $9.1 \%$. Meanwhile, the percentage of female respondents experiencing low risk of occupational stress accounted for $6.7 \%$, moderate risk of occupational stress accounted for $73.3 \%$, and high risk of occupational stress accounted for $20 \%$. The results of the statistical test showed that the
Table 3. Correlation between Gender and Occupational Stress at Sosodoro Djatikoesoemo Bojonegoro Hospital in 2019

\begin{tabular}{cccccccccc}
\hline & \multicolumn{4}{c}{ Occupational Stress Category } & \multirow{2}{*}{ Total } \\
\cline { 2 - 8 } Gender & \multicolumn{2}{c}{ Low } & \multicolumn{3}{c}{ Moderate } & \multicolumn{2}{c}{ High } & & \\
\cline { 2 - 9 } & $\mathbf{n}$ & $\mathbf{\%}$ & $\mathbf{n}$ & $\mathbf{\%}$ & $\mathbf{n}$ & $\mathbf{\%}$ & $\mathbf{N}$ & $\mathbf{\%}$ \\
\hline Male & 3 & 27.3 & 7 & 63.6 & 1 & 9.1 & 11 & 100 \\
Female & 1 & 6.70 & 11 & 73.3 & 3 & 20.0 & 15 & 100 \\
\hline Total & & & & & & & 26 & 100 \\
\hline
\end{tabular}

Table 4. Correlation between Age and Occupational Stress at Sosodoro Djatikoesoemo Bojonegoro Hospital in 2019

\begin{tabular}{|c|c|c|c|c|c|c|c|c|}
\hline \multirow{3}{*}{ Age } & \multicolumn{6}{|c|}{ Occupational Stress Category } & \multirow{2}{*}{\multicolumn{2}{|c|}{ Total }} \\
\hline & \multicolumn{2}{|c|}{ Low } & \multicolumn{2}{|c|}{ Moderate } & \multicolumn{2}{|c|}{ High } & & \\
\hline & $\mathbf{n}$ & $\%$ & $\mathbf{n}$ & $\%$ & $\mathbf{n}$ & $\%$ & $\mathbf{N}$ & $\%$ \\
\hline$<25$ & 0 & 0.0 & 3 & 100 & 0 & 0.0 & 3 & 100 \\
\hline $26-30$ & 2 & 14.0 & 9 & 64.3 & 3 & 21.4 & 14 & 100 \\
\hline $31-35$ & 0 & 0.0 & 2 & 100 & 0 & 0.0 & 2 & 100 \\
\hline $36-40$ & 0 & 0.0 & 1 & 50.0 & 1 & 50.0 & 2 & 100 \\
\hline$>40$ & 2 & 40.0 & 3 & 60.0 & 0 & 0.0 & 5 & 100 \\
\hline Total & & & & & & & 26 & 100 \\
\hline
\end{tabular}

coefficient value was 0.287 , which means there was a strong relationship between sex factor and the risk of moderate occupational stress.

Table 4 shows that in average the age of respondents who experienced a low risk of occupational stress was 37 years old, while the average age of respondents who experienced a risk of moderate and high occupational stress was 31 years old. There were no respondents who experienced very high levels of occupational stress risk. Based on the results of the Spearman Correlation Test, the number obtained was -0.172 , which means that the relationship between age factor and risk of occupational stress was very weak and negative (not unidirectional).

Table 5 shows that the risk of occupational stress was experienced more by respondents who had a Diploma 3 (D3) level of education. Respondents who had a Diploma 3 (D3) level of education had an occupational stress risk of $6.7 \%$, a moderate risk of occupational stress of $80 \%$, and a high risk of occupational stress of $13.3 \%$. Furthermore, respondents who had a Bachelor's degree (S1) had a low occupational stress risk of $22.2 \%$, moderate job stress risk of $55.6 \%$, and a high risk of occupational 
Table 5. Correlation of Education Level with Occupational Stress at Sosodoro Djatikoesoemo Bojonegoro Hospital in 2019

\begin{tabular}{|c|c|c|c|c|c|c|c|c|}
\hline \multirow{3}{*}{$\begin{array}{l}\text { Level of } \\
\text { Education }\end{array}$} & \multicolumn{6}{|c|}{ Occupational Stress Category } & \multirow{2}{*}{\multicolumn{2}{|c|}{ Total }} \\
\hline & \multicolumn{2}{|c|}{ Low } & \multicolumn{2}{|c|}{ Moderate } & \multicolumn{2}{|c|}{ High } & & \\
\hline & $\mathbf{n}$ & $\%$ & n & $\%$ & $\mathbf{n}$ & $\%$ & $\mathbf{N}$ & $\%$ \\
\hline D3 & 1 & 6.7 & 12 & 80.0 & 2 & 13.3 & 15 & 100 \\
\hline S1 & 2 & 22.2 & 5 & 55.6 & 2 & 22.2 & 9 & 100 \\
\hline Profession & 1 & 50.0 & 1 & 50.0 & 0 & 0.0 & 2 & 100 \\
\hline Total & & & & & & & 26 & 100 \\
\hline
\end{tabular}

Table 6. Correlation of Work Period with Occupational Stress at Sosodoro Djatikoesoemo Bojonegoro Hospital in 2019

\begin{tabular}{|c|c|c|c|c|c|c|c|c|}
\hline \multirow{3}{*}{$\begin{array}{c}\text { Years of } \\
\text { service }\end{array}$} & \multicolumn{6}{|c|}{ Occupational Stress Category } & \multirow{2}{*}{\multicolumn{2}{|c|}{ Total }} \\
\hline & \multicolumn{2}{|c|}{ Low } & \multicolumn{2}{|c|}{ Moderate } & \multicolumn{2}{|c|}{ High } & & \\
\hline & $\mathbf{n}$ & $\%$ & $\mathbf{n}$ & $\%$ & $\mathbf{n}$ & $\%$ & $\mathbf{N}$ & $\%$ \\
\hline $1-5$ & 1 & 6.7 & 12 & 80.0 & 2 & 13.3 & 15 & 100 \\
\hline $6-10$ & 2 & 22.2 & 5 & 55.6 & 2 & 22.2 & 9 & 100 \\
\hline $16-20$ & 1 & 50.0 & 1 & 50.0 & 0 & 0.0 & 2 & 100 \\
\hline$>20$ & & & & & & & 26 & 100 \\
\hline Total & & & & & & & 26 & 100 \\
\hline
\end{tabular}

stress of $22.2 \%$. Moreover, respondents who had a professional education level had a risk of low and moderate occupational stress of $50 \%$ each, and no respondent had a high risk of stress. Based on the results of the Spearman Correlation Test, the number -0 was obtained,

Table 6 shows that respondents with a working period of $1-5$ years as many as $16.7 \%$ experienced a risk of occupational stress at a low level, 58.3\% experienced a risk of occupational stress at a moderate level, and $25 \%$ experienced a risk of occupational stress at a high level. Moreover, in the working group of 6-10 years $87.5 \%$ experienced a moderate risk of occupational stress, $12.5 \%$ experienced a high risk of occupational stress, and none of the respondents experienced a low risk of occupational stress. Respondents in the working group of 16-20 years as many as $25 \%$ experienced a low risk of occupational stress, $75 \%$ experienced a moderate risk of occupational stress, and no one experienced a high risk of occupational stress. Furthermore, respondents in the working period group $>20$ years experienced a risk of moderate and high occupational stress accounting for $50 \%$
Table 7. Correlation of Interpersonal Conflict with Occupational Stress at Sosodoro Djatikoesoemo Bojonegoro Hospital in 2019

\begin{tabular}{|c|c|c|c|c|c|c|c|c|}
\hline \multirow{3}{*}{$\begin{array}{c}\text { Interpersonal } \\
\text { Conflict }\end{array}$} & \multicolumn{6}{|c|}{ Occupational Stress Category } & \multirow{2}{*}{\multicolumn{2}{|c|}{ Total }} \\
\hline & \multicolumn{2}{|c|}{ Low } & \multicolumn{2}{|c|}{ Moderate } & \multicolumn{2}{|c|}{ High } & & \\
\hline & $\mathbf{n}$ & $\%$ & n & $\%$ & $\mathbf{n}$ & $\%$ & $\mathbf{N}$ & $\%$ \\
\hline Low & 2 & 16.7 & 8 & 66.7 & 2 & 16.6 & 12 & 100 \\
\hline Moderate & 2 & 14.3 & 10 & 71.4 & 2 & 14.3 & 14 & 100 \\
\hline Total & & & & & & & 26 & 100 \\
\hline
\end{tabular}

Table 8. Correlation Between Workload with Occupational Stress at Sosodoro Djatikoesoemo Bojonegoro Hospital in 2019

\begin{tabular}{|c|c|c|c|c|c|c|c|c|}
\hline \multirow{3}{*}{ Workload } & \multicolumn{6}{|c|}{ Occupational Stress Category } & \multirow{2}{*}{\multicolumn{2}{|c|}{ Total }} \\
\hline & \multicolumn{2}{|c|}{ Low } & \multicolumn{2}{|c|}{ Moderate } & \multicolumn{2}{|c|}{ High } & & \\
\hline & $\mathbf{n}$ & $\%$ & n & $\%$ & $\mathbf{n}$ & $\%$ & $\mathbf{N}$ & $\%$ \\
\hline Moderate & 4 & 26.7 & 10 & 66.7 & 1 & 6.6 & 15 & 100 \\
\hline Weight & 0 & 0.0 & 8 & 72.7 & 3 & 27.3 & 11 & 100 \\
\hline Total & & & & & & & 26 & 100 \\
\hline
\end{tabular}

each, and none of the respondents had a low risk of occupational stress. There were no respondents who experienced the risk of occupational stress in the years of service of 11-15 years. Respondents who experienced a low risk of occupational stress had an average work period of 13 years, and respondents who were at risk of working stress had an average work period of 8 years. Furthermore, respondents who had a high risk of occupational stress had an average work period of 4 years. Based on the Spearman Correlation Test statistical results, the number obtained was -0.248 , which means that the relationship between years of service and risk of occupational stress was very weak and had a negative value (not unidirectional). In addition, respondents who were at risk of working stress had an average work period of 8 years.

Table 7 shows that respondents who had low interpersonal conflict experienced a $16.7 \%$ risk of low occupational stress, $66.7 \%$ risk of moderate occupational stress, and $16.6 \%$ risk of high occupational stress. Meanwhile, respondents who had interpersonal conflict experienced 14.3\% risk of low occupational stress, $71.4 \%$ risk of moderate occupational stress, and $14.3 \%$ risk of high occupational stress. Based on the Spearman Correlation Test statistical results, the number obtained was 0.000 , which means there was no 
Table 9. Correlation of Mental Demands with Occupational Stress at Sosodoro Djatikoesoemo Bojonegoro Hospital in 2019

\begin{tabular}{|c|c|c|c|c|c|c|c|c|}
\hline \multirow{3}{*}{$\begin{array}{c}\text { M e n t a l } \\
\text { Demands }\end{array}$} & \multicolumn{6}{|c|}{ Occupational Stress Category } & \multirow{2}{*}{\multicolumn{2}{|c|}{ Total }} \\
\hline & \multicolumn{2}{|c|}{ Low } & \multicolumn{2}{|c|}{ Moderate } & \multicolumn{2}{|c|}{ High } & & \\
\hline & $\mathbf{n}$ & $\%$ & $\mathbf{n}$ & $\%$ & $\mathbf{n}$ & $\%$ & $\mathbf{N}$ & $\%$ \\
\hline Moderate & 2 & 18.2 & 8 & 72.7 & 1 & 9.1 & 11 & 100 \\
\hline Weight & 2 & 13.3 & 10 & 66.7 & 3 & 20.0 & 15 & 100 \\
\hline Total & & & & & & & 26 & 100 \\
\hline
\end{tabular}

relationship between interpersonal conflict and risk of occupational stress, and there was a positive value (unidirectional).

Table 8 shows the respondents with moderate workloads experienced $26.7 \%$ risk of low occupational stress, $66.7 \%$ risk of moderate occupational stress, and $6.6 \%$ risk of high occupational stress. Meanwhile. respondents with heavy workloads experienced $72.7 \%$ risk of moderate occupational stress, and $27.3 \%$ risk of high occupational stress. Based on the results of the Spearman Correlation Test statistic, the number obtained was 0.421 , which means there was a strong relationship between workload factor and the risk of moderate occupational stress with positive value (unidirectional).

Based on table 9 it can be seen that respondents with moderate mental demands experienced $18.2 \%$ risk of low occupational stress, $72.7 \%$ risk of moderate occupational stress, and $9.1 \%$ risk of high occupational stress. Meanwhile, respondents with severe mental demands experienced $13.3 \%$ risk of low occupational stress, $66.7 \%$ risk of moderate occupational stress, and $20 \%$ risk of high occupational stress. The results of the Spearman Correlation Test statistic showed that the number obtained was 0.140 , which means the relationship between mental demands and the risk of occupational stress was very weak and had a positive value (unidirectional).

Based on table 10 it can be seen that respondents who had control of the job at the less level experienced $18.8 \%$ risk of low occupational stress, $62.5 \%$ risk of moderate occupational stress, and $18.8 \%$ risk of high occupational stress. Moreover, respondents who hadcontrol of the job at the sufficient level experienced $10 \%$ risk of low occupational stress, $80 \%$ risk of moderate occupational stress, and $10 \%$ risk of high occupational stress. Based on the results
Table 10. Correlation Between Job Control with Occupational Stress at Sosodoro Djatikoesoemo Bojonegoro Hospital in 2019

\begin{tabular}{|c|c|c|c|c|c|c|c|c|}
\hline \multirow{3}{*}{ Job Control } & \multicolumn{6}{|c|}{ Occupational Stress Category } & \multirow{2}{*}{\multicolumn{2}{|c|}{ Total }} \\
\hline & \multicolumn{2}{|c|}{ Low } & \multicolumn{2}{|c|}{ Moderate } & \multicolumn{2}{|c|}{ High } & & \\
\hline & $\mathbf{n}$ & $\%$ & $\mathbf{n}$ & $\%$ & $\mathbf{n}$ & $\%$ & $\mathbf{N}$ & $\%$ \\
\hline Less & 3 & 18.8 & 10 & 62.5 & 3 & 18.8 & 16 & 100 \\
\hline Enough & 1 & 10.0 & 8 & 80.0 & 1 & 10.0 & 10 & 100 \\
\hline Total & & & & & & & 26 & 100 \\
\hline
\end{tabular}

of the Spearman Correlation Test, the number obtained was 0.0000 , which means there was no relationship between the job control factor and the risk of occupational stress with a positive value (unidirectional).

\section{DISCUSSION}

\section{Analysis of Age Factor with the Risk of Occupational Stress}

According to Ansori and Martiana, (2017), someone who has grown up has a tendency to be able to control stress conditions compared to someone who is in their adolescence or old age. Thus, age has a relationship with a person's tolerance for the stressors he receives. Someone who is in adulthood has a better tolerance for stress. From the results of the study, it was found the average age of respondents who experienced a low risk of of occupational stress was 37 years old, while the average age of respondents who experienced a moderate and high risk of occupational stress was 31 years old. This can be interpreted as a tendency for younger respondents to have less tolerance for stressors received, thereby increasing the risk of occupational stress.

The results obtained in this research are the same as the results of research conducted by Fitri (2013) which stated that workers who had a younger age were more prone to experience occupational stress. This is because the older the age of a worker, the lower the possibility of him/her suffering from occupational stress. Older workers tend to have better mental health conditions than younger workers do. Similar results are also noted in the study conducted by Ansori and Martiana (2017) suggesting that age had a fairly strong relationship and was not in the direction of the onset of occupational stress. This means that the younger the person's age, 
the higher the occupational stress. However, the results of this research are different from research by Karima (2014) which found that the age variable was weak and positively related to occupational stress, so an increase in the age of workers will increase occupational stress experienced by workers. Another case study conducted by Ibrahim, Amansyah and Yahya (2016) argued that there was no relationship between a person's age and occupational stress. The age variable is difficult to analyze because there are many other factors in individual characteristics that influence its relationship to the risk of occupational stress. In addition, as a person ages, experience, knowledge and sense of responsibility will also increase, which will cover up deficiencies and make a person more adaptable.

\section{Analysis of Gender Factor with the Risk of Occupational Stress}

Based on the results obtained in this study, it is indicated that female had a greater percentage of occupational stress risk than male respondents. The risk of occupational stress at medium and high levels was more experienced by female respondents than men. It can be concluded that female respondents had a tendency to experience risk of occupational stress compared to men. The results of this study are the same as research conducted by Habibi and Jefri (2018) which showed that women had a greater percentage of stress than men. This is possible because female workers have weaker physical abilities than men but have higher job demands (Fitri, 2013). In addition to dealing with stressors which come from the work environment they are also required to prepare family needs such as cooking, taking care of children after returning from work, so they tend to experience fatigue that can trigger stress. In other research from AndrisanoRuggieri et al., (2016) on 269 workers various finance companies in Italy indicated that the level of occupational stress occurred more in women than in men.

\section{Analysis of Years of Service Factor with the Risk of Occupational Stress}

Based on the results of this study, it is indicated that majority of respondents who experienced the risk of occupational stress were in the span of years of service of 1-5 years. Respondents who experienced a low level of occupational stress risk had average years of service of 13 years, those who experienced a moderate level of occupational stress risk had average years of service of 8 years, and those who experienced a high level of occupational stress risk had average years of service of 4 years. This can be interpreted that respondents who have shorter years of service have a greater risk of occupational stress.

These results are in line with research conducted by Fitri (2013) stating that years of service had an important influence in triggering the emergence of occupational stress. Workers with shorter work periods are more likely to experience occupational stress. This can occur due to the fact that the burden of work and pressure that workers have in the first years of work is very large, so it can trigger the emergence of occupational stress. Meanwhile, workers with longer years of service have better abilities and understanding of their work compared to workers who have shorter years of service. This is also the same as the results of research by Irkhami (2015) suggesting that the higher the working period, the lower the occupational stress. However, is the results of this study are different from the results of research conducted by Karima (2014)which stated that the longer work period would lead to a higher level of occupational stress experienced by workers. This is because workers who have longer years of service usually have more work problems compared to workers with fewer years of service, so workers who have longer years of service will experience higher stress levels.

\section{Analysis of Education Level Factor with the Risk of Occupational Stress}

Research conducted by Gobel, Rattu and Akili (2013) showed the relationship between the level of education with occupational stress on nurses who served in the Emergency Room (IGD) Datoe Binangkang City Hospital Kotamabagu. The results showed that all nurses with the lowest education level experienced occupational stress. The results of this study are similar with research conducted by Irkhami (2015) noting that the higher the level of one's education, the lower the stress level. Another research by Shaikhunuddin (2009) also stated that employees with low education level did not always experience occupational stress, and employees with tertiary education also could not be certain that they would be free from the possibility of experiencing occupational stress. 


\section{Analysis of Interpersonal Conflict Factor with the Risk of Occupational Stress}

According to Pramudya (2008), interpersonal conflict is one of the factors that has the potential to cause occupational stress on workers. Interpersonal conflict can have an influence on social support obtained in the workplace. If there are interpersonal conflicts at work, the relationships between workers at work will deteriorate. Thus, it will reduce social support among fellow workers. However, differences of opinion between individuals that can trigger interpersonal conflict in the workplace certainly cannot be eliminated. Instead, these differences can only be controlled so as not to develop into a heated disagreement situation that affects the quality of workers' interpersonal relationships.

The results in this study are in line with research by Habibi and Jefri (2018) suggesting that interpersonal conflict affected to occupational stress. Besides, the study by Karima (2014) also obtained positive results, indicatingthat the higher the interpersonal conflict experienced by workers, the more occupational stress that will be experienced. However, the relationship between the two variables was not significant or it can be said that there was no meaningful relationship.

\section{Analysis of Workload Factor with the Risk of Occupational Stress}

The amount of workload is a condition where workers have a large number of jobs that must be completed in a limited time, yet workers have an inability to handle the workload they face. Excessive workloads or small workloads can cause occupational stress (Andrisano-Ruggieri et al., 2016). The amount of workload that is too much occurs when there are too many assigned jobs, or workers are required to complete the work under time pressure. The results of this study are the same as research conducted by Nurazizah (2017) which showed that the amount of workload was significantly related to the emergence of a number of symptoms of occupational stress. This is also supported by the results of research conducted by Suerni (2012) which found that high workload was significantly associated with the emergence of work dissatisfaction, disturbance, emotional feeling, high levels of depression and the emergence of a number of psychosomatic symptoms. The workload held by nurses in carrying out their duties is not only dealing with people who are sick, but also dealing with various other problems such as demands from the patient's family, regulations, other responsibilities, procedures, and other healthcare teams.

\section{Analysis of Mental Demand Factor with the Risk of Occupational Stress}

Mental demands are a source of stress, especially in a work that requires direct interaction with others, especially in service work. Jobs that require interaction with others have many sources of negative emotions such as sadness, irritability, impatience and so forth (Andrisano-Ruggieri et al., 2016). Moreover, if workers are highly demanded to always be friendly to clients such as nurses to patients. This is not an easy matter for workers to do.

The results of this research are supported by Karima's research (2014) which stated that there was a strong moderate relationship between mental demand and occupational stress with a positive direction, which means that the higher the level of mental demands which is faced by workers, the more occupational stress which will be experienced.

\section{Analysis of Job Control Factor with the Risk of Occupational Stress}

Job control is the ability of workers to cope with the demands to be achieved (Zavanya, 2019). The results of this research indicate that the majority of respondents had less control over work. This is in line with research conducted by Karima (2014), which showed that there was no significant relationship between occupational stress and job control. This is also consistent with Lewin's theory in Stefanus et al. (2015) which explains that the opportunities given to workers to control the work they do can increase the ease for workers when completing their work. Thus, workers can use their abilities to overcome obstacles encountered at work so as to reduce the possibility of workers feeling stressed at work.

\section{CONCLUSION}

Based on the results of research on occupational stress risk on nurses in the Emergency Room (IGD) Sosodoro Djatiekoesoemo Bojonegoro Hospital, it can be concluded that the risk of occupational stress was experienced by respondents. Factors that were related and could increase the risk of occupational stress were gender, personality type, workload and 
mental demands. Meanwhile, factors not related to the risk of occupational stress were interpersonal conflict and job control.

\section{ACKNOWLEDGEMENTS}

The authors would like to thank all nurses in the Emergency Department (IGD) of Sosodoro Djatikoesoemo Bojonegoro Hospital who have been willing to become respondents in this study as well as other parties who have helped in the completion of this research.

\section{REFERENCES}

Amri, A., Manjas, M. and Hardisman, H. (2019) 'Analisis Implementasi Triage, Ketepatan Diagnosa Awal Dengan Lama Waktu Rawatan Pasien di RSUD Prof. DR. MA Hanafiah SM Batusangkar', Jurnal Kesehatan Andalas, 8(3), pp. 484-492.

Andrisano-Ruggieri, R. et al. (2016) 'Inconsistency of sentinel events and no gender difference in the measurement of work-related stress', $S A G E$ Open, 6(1), pp. 1-13.

Ansori, R. R. and Martiana, T. (2017) 'Hubungan Faktor Karakteristik Individu Dan Kondisi Pekerjaan Terhadap Stres Kerja Pada Perawat Gigi', The Indonesian Journal of Public Health, 12(1), pp. 75-84.

Fajrillah (2016) 'Hubungan Stres Kerja Dengan Kinerja Perawat Pelaksana Dalam Rumah Sakit Umum Anutapura', Jurnal Keperawatan Sriwijaya, 3(2), pp. 16-24.

Fitri, A. M. (2013) 'Analisis Faktor-Faktor Yang Berhubungan dengan Kejadian Stres Kerja pada Karyawan Bank (Studi pada Karyawan Bank BMT)', Jurnal Kesehatan Masyarakat, 2(1), pp. $1-10$.

Gobel, R. S., Rattu, J. A. M. and Akili, R. H. (2013) Faktor-Faktor Yang Berhubungan Dengan Stres Kerja Pada Perawat Di Ruang ICU Dan UGD RSUD Datoe Bingkang Kabupaten Bolaang Mangondow. Thesis. Manado : Faculty of Public Health,Universitas Sam Ratulangi

Habibi, J. and Jefri (2018) 'Analisis Faktor Risiko Stres Kerja Pada Pekerja Di Unit Produksi Pt. Borneo Melintang Buana Export', Journal of Nursing and Public Health, 6(2), pp. 50-59.

Handini, E. (2013) Perbaikan Sistem Kerja untuk Meningktkan Produktivias dan Mengurangi Bornout pada Perawat UGD (Studi Kasus: UGD
RSU Haji Surabaya). Thesis. Surabaya. Institut Teknologi Sepuluh Nopember.

Ibrahim, H., Amansyah, M. and Yahya, G. N. (2016) 'Faktor - Faktor yang Berhubungan dengan Stres Kerja pada Pekerja Factory 2 PT . Maruki Internasional Indonesia Makassar', Al-Sihah :Public Health Science Journal, 8(1), pp. 60-68.

Irkhami, F. L. (2015) 'Factor Associated with Job Stress in Divers at PT X.', The Indonesian Journal of Occupational Safety and Health, 4(1), pp. $54-63$.

Karima, A. (2014) Faktor-Faktor Yang Berhubungan dengan Stress Kerja Pada Pekerja di PT X Tahun 2014. Thesis. Jakarta: UIN Syarif Hidayatuallah Jakarta.

Kemenkes, R. (2017) 'Infodatin Perawat 2017.Pdf', pp. $1-12$..

Martyastuti, N. E., Isrofah, I. and Janah, K. (2019) 'Hubungan Beban Kerja Dengan Tingkat Stres Perawat Ruang Intensive Care Unit dan Instalasi Gawat Darurat', Jurnal Kepemimpinan dan Manajemen Keperawatan, 2(1), pp. 9-15.

Nur aini (2019) 'Hubungan Shift Kerja Dengan Kelelahan Kerja Pada Perawat Di Instalasi Rawat Inap Di Rumah Sakit Herna Medan Tahun 2018', Jurnal Ilmiah Penelitian Kesehatan (JUMANTIK), 4(1), pp. 1-12.

Nurazizah (2017) Faktor-faktor yang Berhubungan dengan Stres Kerja Pada Perawat di Ruang Inap Kelas III RS X Jakarta Tahun 2017. Thesis. Jakarta : UIN Syarif Hidayatuallah Jakarta.

Perwitasari, D. T., Nurbeti, N. and Armyanti, I. (2016) 'Faktor-faktor yang Mempengaruhi Tingkatan Stres pada Tenaga Kesehatan di RS Universitas Tanjungpura Pontianak Tahun 2015', Jurnal Cerebellum, 2(3), pp. 44-50.

Pramudya, F. (2008) Faktor yang berhubungan dengan Stres Kerja (Studi Kasus pada Perawat di RSKO tahun 2008). Thesis. Depok : Faculty of Public Health, Universitas Indonesia.

Satmayani, S., Syahrul, S. and Saleh, A. (2018) 'Stres Kerja Pada Perawat di Ruang Perawatan Pediatrik', Jurnal Keperawatan Muhammadiyah, 3(2), pp. 101-109.

Shaikhunuddin (2009) Hubungan Faktor Individu dengan Tingkat Stres Kerja Perawat di ICU RSUD Ibnnu Sina Kabupaten Gresik. Thesis. Surabaya : Faculty of Public Health, Universitas Airlangga.

Stefanus, R. et al. (2015) 'Analisis Kesiapan Manajemen Terhadap Implementasi Perubahan 
Organisasi Pengelolaan SDM Single Grade di PT Pertamina (Persero) Marketing Operation Region V', Jurnal Manajemen Teori dan Terapan, 8(1), pp. $55-70$.

Suerni, T. (2012) Analisis Faktor yang Berhubungan dengan Tingkat Stres Perawat ICU di RSU di Jawa Tengah. Thesis. Depok : Universitas Indonesia

Sulistyawati, N. N. N., Purnawati, S. and Muliarta, I. M. (2019) 'Gambaran Tingkat Stres Kerja Perawat Dengan Kerja Shift Di Instalasi Gawat Darurat RSUD Karangasem', E-Jurnal Medika Udayana, 8(1), pp. 1-6.
Tarwaka (2014) Dasar-dasar Ergonomi dan Implementasi di Tempat Kerja. Surakarta: Harapan Press Surakarta.

Yanto, A. and Rejeki, S. (2017) 'Faktor-faktor yang berhubungan dengan penurunan stres kerja perawat baru Di Semarang', Nurscope : Jurnal Penelitian dan Pemikiran Ilmiah Keperawatan, 3(2), pp. 1-10.

Zavanya, E. (2019) 'Hubungan Job Demand, Job Control, dan Usia dengan Stres Kerja pada Pekerja Konstruksi', Jurnal Kesehatan Masyarakat (Journal of Public Health), 7(4), pp. 54-60. 